Volume 7

Number 1 Fall 2019 Symposium Edition

Pharmaceutical Innovation, Patent Protection,

Article 4 and Regulatory Exclusivities

2-2-2021

\title{
Property and Intellectual Property in Vaccine Markets
}

Ana Santos Rutschman

Saint Louis University School of Law, ana.santosrutschman@slu.edu

Follow this and additional works at: https://scholarship.law.tamu.edu/journal-of-property-law

Part of the Intellectual Property Law Commons

Recommended Citation

Ana Santos Rutschman, Property and Intellectual Property in Vaccine Markets, 7 Tex. A\&M J. Prop. L. 110 (2021).

This Symposia Article is brought to you for free and open access by Texas A\&M Law Scholarship. It has been accepted for inclusion in Texas A\&M Journal of Property Law by an authorized editor of Texas A\&M Law Scholarship. For more information, please contact aretteen@law.tamu.edu. 
Property and Intellectual Property in Vaccine Markets

\author{
Ana Santos Rutschman*
}

I. INTRODUCTION 110

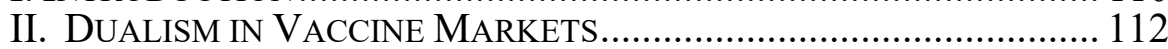

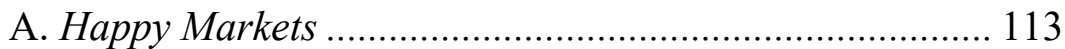

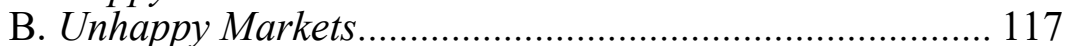

III. VACCINE MARKETS AND INTELLECTUAL PROPERTY .................. 119

A. Intellectual Property as Incentives .................................. 119

B. Transactional Intellectual Property ................................. 123

IV. PROPERTY, INTELLECTUAL PROPERTY AND LIABILITY RULES .. 128

A. IP as Property ..................................................... 128

B. Liability Regimes in IP: A Solution for Vaccine R\&D

During Public Health Crises? ...................................... 132

\title{
I. INTRODUCTION
}

As biopharmaceutical forms of technology, vaccines constitute one of the most important tools for the promotion and maintenance of public health. Tolstoy famously wrote that "[h]appy families are all alike; every unhappy family is unhappy in its own way." Vaccine markets offer perhaps one of the most extreme embodiments of Tolstoy's principle ${ }^{2}$ in the field of biopharmaceutical innovation.

DOI: https://doi.org/10.37419/JPL.V7.I1.4

*Assistant Professor of Law, Saint Louis University School of Law, Center for Health Law Studies and Center for Comparative and International Law. S.J.D., LL.M., Duke Law School. I am grateful to the participants at the Texas A\&M University Journal of Property Law 2019 Fall Symposium for helpful comments and insights.

1. Much more structured arguments have been made formalizing a so-called Anna Karenina principle in other academic areas. See, e.g., Dwayne R. J. Moor, The Anna Karenina Principle Applied to Ecological Risk Assessments of Multiple Stressors, 7 HuM. \& ECOLOGICAL RISK ASSESSMENT: AN INT'L J. 231 (2001).

2. Principle is used here in a non-formalized way, merely as an indication of the narrative and prescriptive emphasis on the malfunctions of IP regimes in connection with vaccine R\&D, as opposed to the success stories - or "happy" narratives - surrounding vaccines for which there is both demand and adequate supply. 
Vaccines are often described as one of the most unprofitable types of biopharmaceutical goods, under-incentivized from a research and development ("R\&D") perspective, and routinely failing to attract sufficient investment from traditional funders in biopharma. ${ }^{3}$ In this sense, and despite the scientifically well-established value of vaccines from a public health perspective, vaccine markets are often portrayed as a collection of unhappy families. ${ }^{4}$ Yet, at least throughout the developed world, there are plenty of examples of steadily profitable vaccine markets, as is the case of recently developed vaccines targeting the human papilloma virus ("HPV"). 5

This Essay begins by mapping the dualism in vaccine R\&D and commercialization, describing both "happy" and "unhappy" markets. It then connects the development of new vaccines with the default legal regime to promote innovation in the biopharmaceutical arena: the patent system. In exploring possible solutions for transactional problems arising in connection with the development of vaccine technology, this Essay asks whether the rights covering vaccine technologies are best understood as property rights or as something else. This inquiry is of course but a fragment of a much larger interrogation of the nature and mechanics of intellectual property systems: are intellectual property rights - and rights arising out of the grant of patents in particular-more like property or akin to something else? Arguing that under the current noncommittal position of the Supreme Court there is room for understandings of patent rights that are not property-centric, ${ }^{6}$ this Essay concludes by exploring how less property-like protection - in the form of a liability regime for critical components of vaccine technology - can remove some of the most salient transactional obstacles to the development and commercialization of new and better vaccines.

3. See, e.g., Ruth Young et al., Developing New Health Technologies for Neglected Diseases: A Pipeline Portfolio Review and Cost Model, GATES OPEN RESEARCH 1, 1 (Feb. 19, 2020), https://gatesopenresearch.org/articles/2-23/v2 [https://perma.cc/93N9-DSXG] (finding chronic and R\&D lacunas for several priority vaccines).

4. The term family applied here further reflects the fact that vaccines for certain families or types of pathogens fare better than others. See infra Parts I.A-B.

5. See infra Part I.B.

6. See Oil States Energy Servs., LLC v. Greene's Energy Grp., LLC, 138 S. Ct. 1365, 1365 (2018). 


\section{DuALISM In VACCINE MarketS}

Vaccines have long been recognized in scientific literature and practice as one of the most cost-effective ways of preventing and mitigating the burden of disease. ${ }^{7}$ The development of vaccines targeting new pathogens, as well as the improvement of existing vaccines, remains a crucial component of the public health preparedness perspective, ${ }^{8}$ as evidenced by the emphasis placed on vaccine R\&D during the COVID-19 pandemic. ${ }^{9}$

Some vaccines become commercially successful. ${ }^{10}$ For instance, Merck's vaccine targeting HPV ("Gardasil") has become a best-seller, increasing its yearly revenue from $\$ 1.7$ to $\$ 3.2$ billion in $2018 .{ }^{11}$ The vast majority of vaccines for infectious diseases, however, are deemed unprofitable by industry standards. ${ }^{12}$ These diseases,

7. See F.E. Andre et al., Vaccination Greatly Reduces Disease, Disability, Death and Inequity Worldwide, Bull. World HeAlth OrG. (Feb. 2, 2008), https://www.who.int/bulletin/volumes/86/2/07-040089/en/

[https://perma.cc/5M2D-AS43]; Vanessa Rémy et al., Vaccination: The Cornerstone of an Efficient Healthcare System, 3 J. MKT. ACCESS \& HEALTH POL'Y 27041 (2015), https://www.tandfonline.com/doi/pdf/10.3402/jmahp.v3.27041?need Access=true [https://perma.cc/S668-QDKM]. See also Bruce Gellin et al., Vaccines as Tools for Advancing More than Public Health: Perspectives of a Former Director of the National Vaccine Program Office, 32 CLINICAL INFECTIOUS DisEASES 283, 283 (2001), https://academic.oup.com/cid/article/32/2/283/320376 [https://perma.cc /5WQ9-KE6N].

8. See, e.g., Peter F. Wright, Vaccine Preparedness - Are We Ready for the Next Influenza Pandemic?, 358 NEW ENGL. J. MED. 2540, 2540 (2008), https://www.nejm.org/doi/pdf/10.1056/NEJMp0803650?articleTools=true

[https://perma.cc/JQ27-W5BQ] (discussing preparedness in connection with the development of a universal flu vaccine).

9. See, e.g., Tung Thanh Le et al., The COVID-19 Vaccine Development Landscape, NATURE REV. DRUG Discovery (Apr. 9, 2020), https://www.nature.com/articles/d41573-020-00073-5 [https://perma.cc/X7VFZFGT] (surveying numerous vaccine R\&D vaccine efforts during the COVID-19 pandemic).

10. See, e.g., Bourree Lam, Vaccines Are Profitable, So What?, The AtLanTiC (Feb. 10, 2015), https://www.theatlantic.com/business/archive/2015/02/vaccinesare-profitable-so-what/385214/ [https://perma.cc/TLN2-G4P4].

11. See Trefis Team, Merck's \$3 Billion Drug Jumped To 4x Growth Over Previous Year, FORBES (Oct. 4, 2019, 4:30 AM), https://www.forbes.com/sites/greatspeculations/2019/10/04/mercks-3-billion-drugjumped-to-4x-growth-over-previous-year/\#5bc71 e0c6294 [https://perma.cc/9ZBNHZ2K]; see also Ed Silverman, Switching to Newest HPV Vaccine Can Save Billions in Health Care Costs, Study Says, StAT (Apr. 18, 2016), https://www.statnews.com/pharmalot/2016/04/18/sex-vaccine-merck-gardasil/ [https://perma.cc/GM3V-BZKX].

12. See, e.g., Luis Barreto, The Industry Perspective, in VACCINES: PREVENTING Disease \& Protecting Health 304, 308 (Ciro A. de Quadros ed., 2004). 
which historically have affected populations located predominantly in the Global South, are becoming increasingly globalized, as illustrated by the recent outbreaks of Ebola, Zika, and COVID-19. ${ }^{13}$

Thus, vaccine markets present innovators, funders, and policyand lawmakers with a split landscape. A restricted number of vaccines like Gardasil fare well under contemporary market-based approaches - and, in this sense, make for "happy" narratives within the vaccine innovation ecosystem. But the majority of vaccines needed to address the burden posed by infectious diseases makes for an "unhappy" narrative for numerous reasons, ranging from scientific (viruses mutate quickly, for instance) to market-driven (certain patient populations are so small that, from the perspective of $R \& D$ funders, return on investment is unlikely). ${ }^{14}$ The following sections provide an account of this dualism.

\section{A. Happy Markets}

In a report to Congress in 2018, the Department of Health and Human Services characterized the vaccine R\&D ecosystem in the United States as "successful" and as a "well established" enterprise, which has brought "innovative and new and improved vaccines to the market." "At the time, there were over 120 vaccine candidates under development, with R\&D conducted in collaborative models involving heterogenous players including the public sector, pharmaceutical companies, universities, non-profit organizations, and the private sector. ${ }^{16}$

The development of certain vaccines has always been a priority in the United States. ${ }^{17}$ The best illustration of the alignment

13. See Lance Salker et al., Globalization and Infectious Diseases: A Review of the Linkages, WORLD HEALTH ORG. (2004), https://www.who.int/tdr/publications/documents/seb_topic3.pdf [https://perma.cc/HJ65-FJWK].

14. See generally Ana Santos Rutschman, The Intellectual Property of Vaccines: Takeaways from Recent Infectious Disease Outbreaks, 118 MICH. L. REV. ONLINE 170,170 (2020).

15. U.S. Dep't of Health and Human Servs., Encouraging Vaccine INNOVATION: PROMOTING THE DEVELOPMENT OF VACCINES THAT MiNiMIZE THE BURDEN OF INFECTIOUS DisEASES IN THE 21st CENTURY REPORT TO CONGRESS 3 (Dec. 2017), https://www.hhs.gov/sites/default/files/encouraging vaccine innovati on_2018_final_report.pdf [https://perma.cc/8DWW-VBD2] [hereinafter ENCOURAGING VACCINE INNOVATION].

16. Id. at $5-6$.

17. Id. at 7 (noting that "[p]ublic health priorities have historically been evident 
between public health imperatives and support for R\&D is perhaps the development of the first polio vaccine. ${ }^{18}$ Polio is a crippling disease that may result in paralysis or death. ${ }^{19}$ Outbreaks of the disease intensified from the late nineteenth century onwards, triggering a race among scientists to develop competing vaccine candidates in the 1940 s and early $1950 \mathrm{~s} .{ }^{20}$ In 1952 , the disease, which affected between 25,000 and 50,000 people every year in the United States, killed 3,000 children. $^{21}$ The first polio vaccine was made available in the United States in $1955 .^{22}$ By 1961, the rates of polio infection had dropped by a factor of $17 .{ }^{23}$ Largely due to the R\&D efforts that took place in the mid-twentieth century, ${ }^{24}$ polio has been reduced by $99 \%{ }^{25}$

In addition to responding to pressing public health needs, the race to develop a polio vaccine unfolded against an $R \& D$ and funding backdrop that remains unmatched in the history of vaccine development. ${ }^{26}$ The mid-twentieth century remains one of the golden periods - if not the golden period - of vaccine development. ${ }^{27}$ Both the number of licensed vaccine manufacturers and the number of new vaccines entering the market remain unmatched. For instance, the estimated number of vaccines commercialized in the 1940s was

to stakeholders due to the clear disease burden of many infectious agents (e.g., polio) and public health demand for vaccines").

18. See generally DAVID M. OSHINSKY, POLIO: An AMERICAN StORY 1 (2006).

19. Tuuli Hongisto, Poliomyelitis (polio), World Health Org., https://www.who.int/health-topics/poliomyelitis\#tab=tab 1

[https://perma.cc/F4SH-4UL5] (last visited June 12, 2020).

20. See Anda Baicus, History of Polio Vaccination, 1(4) World J. VIrol. 108, 108-110 (2012).

21. Gilbert King, Salk, Sabin and the Race Against Polio, Smithsonian Mag. (Apr. 3, 2012), https://www.smithsonianmag.com/history/salk-sabin-and-the-raceagainst-polio-169813703/ [https://perma.cc/9ZHQ-C7BN].

22. Baicus, supra note 17, at 109.

23. Id. (reporting a drop in infection rates from " 13.9 cases per 100,000 [people] in 1954 to 0.8 cases per 100,000 [people] in 1961" in the United States).

24. Combined with immunization campaigns, as well as surveillance and monitoring practices.

25. 10 Facts on Polio Eradication, WORLD HEALTH ORG., https://www.who.int/features/factfiles/polio/en/ [https://perma.cc/E6WK-TPD5] (last updated Apr. 2007).

26. See generally U.S. CONGREss, OfFice of TeChnology Assessment, A REVIEW OF SElECted FEDERAL VACCINE ANd IMMUNIZATION POLICIES, BASEd ON CAse Studies of PNeumococcal VAccine (1979) [hereinafter OTA Review] (describing the vaccine R\&D landscape in the United States through the early and mid-twentieth century).

27. Ana Santos Rutschman, The Vaccine Race in the $21^{\text {st }}$ Century, 61 ARIz. L. REV. 729, 738-744 (2019) [hereinafter Vaccine Race]. 
around $60,3^{28}$ at that point, the United States market had over 50 vaccine manufacturers, in sharp contrast with single digits from the 1990s onwards. ${ }^{29}$

In addition to the historical market(s) for vaccines in the 1940s and $1950 \mathrm{~s},{ }^{30}$ there are currently several vaccines with stable and sizable markets. In the United States, the federal government recommends the administration of certain vaccines to almost all individuals based on age and medical indications. ${ }^{31}$ These include vaccines against polio, tetanus, and measles, mumps, and rubella (MMR). ${ }^{32}$ The Affordable Care Act imposes insurance coverage of the Centers for Disease Control (CDC)-recommended vaccines, which in practice translates into the inexistence of cost-sharing or co-pay requirements for patients. $^{33}$ The tandem created by federal recommendation of vaccines and mandatory coverage thus fuels both R\&D and commercialization of vaccines falling under this umbrella.

Moreover, there are cases in which public- and private-sector players are motived to engage in $\mathrm{R} \& \mathrm{D}$ even though the market is short-lived or there are scientific impediments to vaccine development. The example of flu vaccines is instructive. The Affordable Care Act proviso covers existing flu vaccines, which have to be developed each year to respond to mutating pathogens. ${ }^{34}$ On the

28. See Kendall Hoyt, Long Shot: Vaccines for National Defense 180 86 (2012). See Rutschman, Vaccine Race, supra note 27, at 742; see also U.S. FoOD \& DRUG Admin., VACCINES LICENSEd FOR USE IN THE UNITED STATES, https://www.fda.gov/vaccines-blood-biologics/vaccines/vaccines-licensed-useunited-states [https://perma.cc/8RU5-9JS3] (providing an overview of currently licensed vaccines in the United States market).

29. Rutschman, supra note 14 , at 174.

30. OSHINSKY, supra note 18, at 5 (considered transversally as to include different types of vaccines and vaccine technology, as well as different pathogens targeted by a multiplicity of R\&D projects).

31. See U.S. Ctrs. Disease Control \& Prevention, ReCOMMEnded Child AND ADOLESCENT IMMUNIZATION SCHEDULE FOR AGES 18 YEARS OR YOUNGER, UNITED STATES, 2020, https://www.cdc.gov/vaccines/schedules/hcp/imz/childadolescent.html (last reviewed Feb. 3, 2020) [https://perma.cc/BCD4-XZ54].

32. U.S. DEP'T HeAlTh HuM. SERV., VACCINES \& IMMUnizATIONS, https://www.hhs.gov/programs/prevention-and-wellness/vaccines-and-

immunizations/index.html [https://perma.cc/Z8FF-SCDU] (last reviewed Jan. 13, 2020).

33. See U.S. Dep't Health Hum. Serv, Where And How to Get Vaccines, https://www.hhs.gov/ash/oah/adolescent-development/physical-health-andnutrition/vaccines/where-and-how-to-get-vaccines/index.html [https://perma.cc/6XGG-872U] (last reviewed Aug. 6, 2019).

34. See U.S. Ctrs. Disease Control \& Prevention, How the Affordable 
other hand, universal flu vaccines have long posed scientific challenges during $R \& D$ stages and have yet to be successfully developed. Nevertheless, R\&D in this area continues to attract interest from the public and private sectors alike. ${ }^{35}$ While not very common, this is not the only example of a field of vaccine R\&D that remains well-populated-R\&D on vaccine candidates targeting respiratory syncytial virus, which causes mild symptoms in most patients but can lead to severe consequences for infant and older populations, ${ }^{36}$ attracts sustained interest from private-sector firms. ${ }^{37}$

Finally, as documented above, the recent success of Gardasil speaks to the possibility of blockbusters in vaccine markets. However, even blockbuster vaccines generate much less revenue than blockbuster pharmaceutical or biopharmaceutical products in other areas. For instance, best-selling biologics generate tens of billions in revenue - the world's best-selling drug in any category, Humira, has reached $\$ 20$ billion globally. ${ }^{38}$ Gardasil, on the other hand, made headlines for reaching $\$ 3$ billion in revenue in $2018 .^{39}$

Outside the "happy" scenarios surveyed above, this disparity in revenue stream makes investment in vaccine $R \& D$ prospectively unappealing to investors in the private sector. As the public sector lacks the financial and infrastructural capacity to develop and commercialize vaccines exclusively on its own, large R\&D lacunasand potentially serious public health consequences-arise in

CARE ACT INCREASES ACCESS TO INFLUENZA VACCINATION FOR HEALTH CARE PERSONNEL, https://www.cdc.gov/flu/toolkit/long-term-care/aca.htm [https://perma .cc/DN3V-RUVJ] (last reviewed Nov. 2, 2020).

35. ENCOURAGING VACCINE INNOVATION, supra note 15, at 7 (noting that "The development of certain vaccines - for example, universal influenza vaccines and respiratory syncytial virus (RSV) vaccines for infants - is considered a high priority as reflected in the number of companies working on these vaccine targets").

36. U.S. CTRS. DisEASE CONTROL \& PREVENTION, RESPIRATORY SYNCYTIAL VIRUS INFECTION (RSV), https://www.cdc.gov/rsv/index.html [https://perma.cc/2N XV-LP9F] (last reviewed June 26, 2018).

37. See id.

38. See, e.g., Alex Keown, AbbVie Raises 2019 Profit Target Amid Sliding Global Humira Sales, BIOSPACE (July 26, 2019), https:/www.biospace.com/article/ despite-sliding-global-humira-sales-abbvie-beasts-analysts-estimates/ [https:// perma.cc/HL3L-53YQ].

39. Trefis Team, Merck's $\$ 3$ Billion Drug Jumped To 4x Growth Over Previous Year, FORBES (Oct. 4, 2019, 4:30 AM), https://www.forbes.com/sites/great speculations/2019/10/04/mercks-3-billion-drug-jumped-to-4x-growth-overprevious-year/\#5bc71e0c6294 [https://perma.cc/9ZBN-HZ2K]. 
connection with vaccines with estimated small markets. This Essay now turns to these "unhappy" scenarios in vaccine R\&D.

\section{B. Unhappy Markets}

In early 2020, a novel strain of coronavirus made headlines as it spread across the world. ${ }^{40}$ As the magnitude of the outbreak became apparent, the U.S. National Institutes of Health ("NIH") were among the first institutions funding the development of a coronavirus vaccine. ${ }^{41}$ The director of the U.S. National Institute of Allergy and Infectious Diseases described the process of getting private-sector companies to join the project as "very difficult and very frustrating." During the very early stages of the coronavirus outbreak, no large pharmaceutical company expressed interest in partnering with $\mathrm{NIH} .{ }^{43}$ Eventually, major vaccine manufacturers like Johnson \& Johnson, Novavax, Inovio, and Gilead started developing vaccines targeting the novel coronavirus. ${ }^{44}$ Even at that point, many commentators remained concerned that "if the outbreak slow[ed] down, industry interest in a vaccine could plummet." 45

The initial reluctance from the private sector in engaging in vaccine $R \& D$ - which now registers as almost infinitesimal within the timeline of the extended outbreak-illustrates the problems surrounding vaccines from an innovation perspective. Even when outbreak-induced funding becomes available for expedited R\&D, vaccines remain unappealing as an investment prospect to the players with the greatest manufacturing ability and the deepest pockets.

While the development and deployment of vaccines against infectious diseases have led to the eradication of some diseases and

40. U.S. CTRS. Disease Control \& Prevention, Coronavirus Disease 2019 (COVID-19) GLOBAL COVID-19, https://www.cdc.gov/coronavirus/2019ncov/global-covid-19/index.html [https://perma.cc/BT9G-ZSDV] (last updated Nov. 5, 2020).

41. Nicholas Florko, Major Drug Makers Haven't Stepped Up to Manufacture NIH Coronavirus Vaccine, Top U.S. Health Official Says (Feb. 11, 2020), https:/www.statnews.com/2020/02/11/major-drug-makers-havent-stepped-up-tomanufacture-coronavirus-vaccine-top-u-s-health-official-says/

[https://perma.cc/32GG-FX6U].

42. Id.

43. Id.

44. Alex Lee, Why We Shouldn't Pin Our Hopes on a Coronavirus Vaccine, WIRED (Feb. 6, 2020), https://www.wired.co.uk/article/coronavirus-vaccine-china [https://perma.cc/9NFK-S5AU].

45. Id. 
while they prevent high levels of morbidity and mortality associated with many other diseases, most markets for vaccines targeting infectious diseases are generally considered unprofitable. ${ }^{46}$ To begin, the indicated population tends to be smaller ${ }^{47}$ than populations in markets for pharmaceutical products targeting prevalent diseases, including a multitude of cardiovascular, oncological and autoimmune conditions. $^{48}$ Moreover, there are long-recognized difficulties in calculating savings to health systems stemming from vaccine use. ${ }^{49}$ And even for players motivated to engage in vaccine $R \& D$, there are hurdles that were largely absent in the polio days. While the golden age of vaccine development in the mid-twentieth century translated into numerous new vaccines entering the market, $R \& D$ on remaining targets has become substantially more complex from a scientific perspective, requiring exponentially higher investment levels than before. $^{50}$

These dynamics cause $R \& D$ on numerous vaccine targets to be chronically underfunded. ${ }^{51}$ This Essay now turns to the default legal regime that should, in principle, cure some of the imbalances affecting incentives frameworks for vaccine $\mathrm{R} \& \mathrm{D}$ - as Part III will show, however, that is not the case in practice.

46. EnCOURAGING VACCINE InNOVATION, supra note 15 ("The prevailing business model prioritizes vaccine candidates with large markets; yet market sizes are likely smaller for many remaining targets"). For a summary of the characteristics of vaccines that have traditionally rendered them less attractive from an R\&D perspective, see generally Rutschman, The Intellectual Property of Vaccines: Takeaways from Recent Infectious Disease Outbreaks, 118 MicH. L. REV. 170, 170 (2020).

47. A recent exception to this rule has been the case of the COVID-19 pandemic, during which there was pronounced demand-and at global level-for a vaccine targeting the underlying pathogen. See, e.g., Ed Yong, How the Pandemic Will End, THE ATLANTIC (Mar. 25, 2020), https://www.theatlantic.com/health/archive/2020/ 03/how-will-coronavirus-end/608719/ [https://perma.cc/6AV8-4WWA]; Laura Spinney, Coronavirus Vaccine: When Will We Have One?, ThE GuARDIAN (Apr. 15, 2020), https:/www.theguardian.com/world/2020/apr/15/coronavirus-vaccinewhen-will-we-have-one-covid-19 [https://perma.cc/Y4Y7-N42J].

48. See e.g., Kate Cox, What Are The 10 Biggest Money-Making Prescription Drugs, And What Do They Treat?, CONSUMER REPORTS (Sept. 26, 2017), https://www.consumerreports.org/consumerist/what-are-the-10-biggest-moneymaking-prescription-drugs-and-what-do-they-treat [https://perma.cc/D2YS-2L5Q].

49. See e.g., Mondher Toumi \& Walter Ricciardi, The Economic Value of Vaccination: Why Prevention is Wealth, 3 J. MKT. ACCESS HEALTH POL'Y (2015).

50. Id.

51. See Ruth Young et. al., supra note 3, at 1. 


\section{VACCINE MARKETS AND INTELLECTUAL PROPERTY}

As seen above, many types of vaccines needed to prevent or mitigate the effects of infectious diseases fail to attract appropriate levels of investment, if any. Because intellectual property remains the primary legal regime designed to incentivize investment in underfunded areas, this Essay now turns to the role and shortcomings of patent regimes in connection with vaccine $R \& D$.

There is an additional moment in the vaccine innovation ecosystem in which intellectual property frameworks are relevant: as a vaccine candidate progresses through the $R \& D$ pipeline, patent rights often arise in connection with individual components of a single vaccine. ${ }^{52}$ If different, non-cooperating entities patent discrete components needed to make a vaccine - or if an entity holding rights over an entire vaccine fails to bring it to market - intellectual property may erect new hurdles to the commercialization of vaccines that were able to overcome shortcomings in incentives frameworks.

Part A briefly summarizes problems related to the incentivesenhancing function of patent regimes, while Part B addresses problems posed by transactional inefficiencies within patent regimes covering vaccine technology.

\section{A. Intellectual Property as Incentives}

Contemporary intellectual property regimes are often cast as systems of incentives. ${ }^{53}$ In exchange for the ability to exclude wouldbe competitors from the market for a period of time, innovators have an incentive to embark on risky and resource-intensive endeavors that might otherwise never receive funding. ${ }^{54}$ Patents embody this

52. The Vaccine Race, supra note 27 at 762 (surveying the rise of an intellectual property culture surrounding vaccine $R \& D)$.

53. See e.g., Stephen M. Maurer, Intellectual Property Incentives: Economics and Policy Implications, in OXFORD HANDBOOK OF INTELLECTUAL PROPERTY LAW 1, 1 (Rochelle Dreyfus \& Justine Pila, eds., 2018); see also WiLliAM FISHER, Theories OF INTEllectual Property, CyBER HARV. (1987), https://cyber.harvard.edu/people/tfisher/iptheory.pdf [https://perma.cc/R45K2R57] (highlighting a different framing IP theories complementing the incentives narrative).

54. See Rebecca S. Eisenberg, The Problem of New Uses, 5 Yale J. HeAlth POL'Y L. \& ETHICS 717, 720 (2005) (explaining how this view of intellectual property has been particularly resonant in the pharmaceutical and biopharmaceutical areas). 
utilitarian ethos perhaps better than any other domain in intellectual property. $^{55}$

If the prospective purpose of patents functioned as (at least nominally) intended in the area of vaccines, then the possibility of market exclusivity should, to some extent, outweigh the risk and cost associated with vaccine $R \& D$. Because vaccines are socially desirable, there would be an alignment between public health imperativesdevelopment, production, and distribution of one of the most cost effective tools for preventing disease or mitigating its burden - and the catalytic function of the patent system in fields of $R \& D$ that can rely on market prospectivity the least.

In practice, however, the patent system on its own is incapable of incentivizing sustained $R \& D$ on many types of vaccines we collectively need, ${ }^{56}$ including vaccines for which the required scientific knowledge exists prior to the outbreak of an infectious disease. ${ }^{57}$ It should be noted that, apart from the historically ingrained pervasiveness of patent regimes in contemporary innovation infrastructure, ${ }^{58}$ there is no particular reason why vaccine $R \& D$ should be best incentivized through intellectual property incentives. After all, intellectual property offers a transversal mode of promoting innovation, with the patent system being technology agnostic — at least in its overall design. ${ }^{59}$

To be sure, vaccines are not the only type of product for which intellectual property incentives have shown to be insufficient time and

55. See e.g., Patlex Corp. v. Mossinghoff, 758 F.2d 594, 599 (Fed. Cir. 1985) (stating that the "encouragement of investment-based risk is the fundamental purpose of the patent grant, and is based directly on the right to exclude"); F. Scott Kieff, Property Rights \& Property Rules for Commercializing Inventions, 85 MINN. L. REV. 697 (2001) (noting that "[ $\mathrm{t}]$ he foundation for the American patent system is purely economic"); see generally ROBERT P. MERGES \& JOHN F. DUFFY, PATENT LAW \& POL'Y 1,1 (7th ed. 2017).

56. See Rutschman, supra note 14.

57. See Ana Santos Rutschman, IP Preparedness for Outbreak Diseases, 65 UCLA L. REV. 1200, 1219 (2018) (describing the development of an Ebola vaccine candidate before the 2014-16 Ebola outbreak and how it failed to attract privatesector support for clinical testing).

58. Which, admittedly, is no small feature of the current innovation ecosystem.

59. See Dan L. Burk \& Mark A. Lemley, Is Patent Law Technology-Specific?, 17 BERKELEY TECH. L. J. 1155, 1156 (2002) (noting that "[w]ith very few exceptions, the [patent] statute does not distinguish between different technologies in setting and applying legal standards.). 
time again. Other categories include antibiotics, ${ }^{60}$ orphan diseases, ${ }^{61}$ and neglected tropical diseases (such as Chagas disease, dengue, or leishmaniasis). ${ }^{62}$ Moreover, not all underinvestment in vaccine R\&D is rooted in insufficiency of intellectual property incentives; scientific complexity in many areas of vaccine R\&D has increased substantially from the heyday of polio research. ${ }^{63}$

These additional factors further complicate the economics and dynamics of vaccine R\&D. An overview of the current landscape for vaccine development shows that most $R \& D$ efforts ${ }^{64}$ are currently centered on cancer vaccines ${ }^{65}$ - precisely one of the more difficult types of vaccine R\&D from a scientific perspective-as opposed to simpler forms of vaccine development, such as vaccines used to target pathogens causing infectious disease. ${ }^{66}$

60. See e.g., Aaron S. Kesselheim \& Kevin Outterson, Fighting Antibiotic Resistance: Marrying New Financial Incentives to Meeting Public Health Goals, HEALTH AFFAIRS. (Sept. 2010) https://www.healthaffairs.org/doi/full/10.1377

/hlthaff.2009.0439 [https://perma.cc/FE5H-V7DX].

61. In the United States, orphan diseases are defined as conditions affecting fewer than 200,000 people. Orphan Products: Hope for People with Rare Diseases, U.S. FOOD \& DRUG ADMIN., (Mar. 1, 2018) https://www.fda.gov/drugs/druginformation-consumers/orphan-products-hope-people-rare-diseases

[https://perma.cc/6BC9-H9Z2]; see generally Orphan Drug Act, Pub. L. No. 97-414, 96 Stat. 2049 (1983) [https://perma.cc/UTU5-9SNK].

62. Neglected Tropical Diseases, WORLD HEALTH ORG., https://www.who.int/neglected diseases/diseases/en/ [https://perma.cc/68VX25WX] (last visited June 21, 2020).

63. See Stanley Plotkin et al., The Complexity and Cost of Vaccine Manufacturing - An Overview, 35 VACCINE 4064, 4066 (2017), https:/www.ncbi.nlm.nih.gov/pmc/articles/PMC5518734/ (describing the overall complexity of vaccine manufacturing); Barney S. Graham, G E Ledgerwood, \& G J Nabel, Vaccine Development in the Twenty-First Century: Changing Paradigms for Elusive Viruses, 86 CliniCAL PHARMA. \& THERAPEUTICS 234, 235 (2009), https://www.ncbi.nlm.nih.gov/pmc/articles/PMC2931821/

[https://perma.cc/YMA2-AQTQ] (noting that "[t] he viruses for which new vaccines are now in development have also become more challenging"); Morven E. Wilkie \& Helen McShane, TB Vaccine Development: Where Are We and Why is it So Difficult?, 70 THORAX 299, 299 (2015), https://thorax.bmj.com/content/70/3/299 [https://perma.cc/KGA2-LDW2] (exemplifying the scientific challenges in the field of vaccine R\&D targeting tuberculosis).

64. Outside the context of a pandemic like COVID-19.

65. See Cynthia Liu, Global Vaccine Trends: R\&D and Market Insights Driving New Opportunities, AM. CHEMICAL Soc. (May 3, 2019), https:/www.cas.org/blog/global-vaccine-trends-rd-and-market-insights-drivingnew-opportunities [https://perma.cc/74X8-V5GR].

66. See generally Susanne Rauch et al., New Vaccine Technologies to Combat Outbreak Situations, 9 FRONTIERS IMMUNOLOGY (2018), https://www.ncbi.nlm.nih.gov/pmc/articles/PMC6156540/pdf/fimmu-09-01963.pdf 


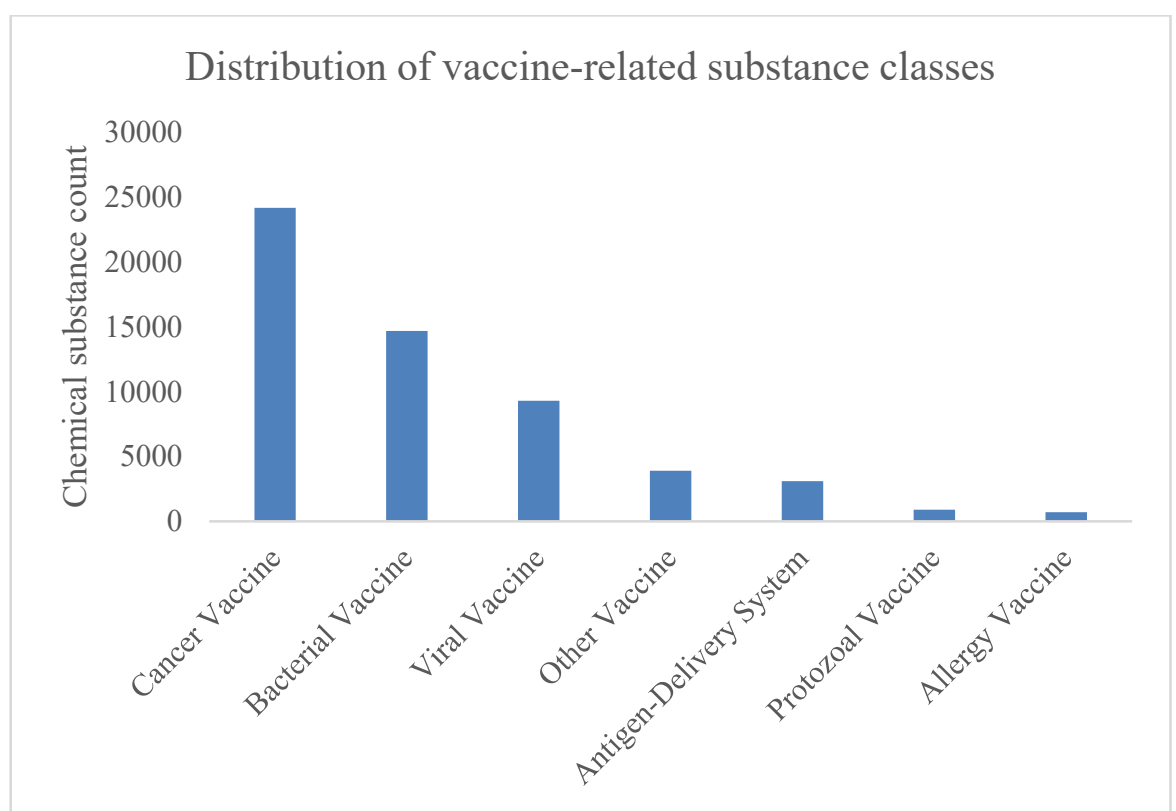

Figure 1: Distribution of vaccine-related substance classes (according to chemical substance count $)^{67}$

As a system of incentives, if intellectual property were truly able to correct for shortcomings in market-driven $R \& D$ pipelines, then we should have relatively robust levels of vaccine $R \& D$ in the field of infectious diseases - the group of pathogens causing outbreaks affecting the health of individuals and communities locally, transnationally, and now, with diseases like COVID-19, at a global level. ${ }^{68}$ Because the toll of these diseases can be enormous, R\&D systems calibrated primarily by public health imperatives would allocate abundant resources to vaccine R\&D in this space. Failing this, the utilitarian intellectual property narrative would then have the

(describing different types of vaccine technology used in the context of infectious disease).

67. See generally Cynthia Liu, Global Vaccine Trends: $R \& D$ and Market Insights Driving New Opportunities, AM. CHEMICAL Soc. (May 3, 2019), https://www.cas.org/blog/global-vaccine-trends-rd-and-market-insights-drivingnew-opportunities [https://perma.cc/42XF-YUF5].

68. See Coronavirus Disease (COVID-2019) Situation Reports, World Health ORG., https://www.who.int/emergencies/diseases/novel-coronavirus-2019/situation -reports/ [https://perma.cc/VDS2-MRVR] (reporting over 7.5 million cases of infection and close to 500,000 deaths globally on June 14,2020). 
patent system artificially create incentives to $R \& D$ that would, in substantial ways, offset the commercially unappealing prospects of many vaccines targeting infectious diseases. ${ }^{69}$ However, that has not been the case. ${ }^{70}$ Even against the backdrop of the COVID-19 pandemic - an event of unprecedented magnitude in the age of biotechnology - the race to develop new vaccines has been both tempered by profitability considerations ${ }^{71}$ and renewed discussion about the need for non-IP incentives. ${ }^{72}$

It is in this sense that vaccines, as opposed to several other types of biopharmaceutical products, ${ }^{73}$ often present would-be funders and developers with "unhappy" R\&D prospects, particularly in the field of infectious diseases - one of the areas where, paradoxically, the public health need is often the greatest.

\section{B. Transactional Intellectual Property}

Now let us consider the case of vaccine candidates in the infectious disease space that manage to attract sufficient funding for the later stages of $R \& D$. This occurs when there is sufficient momentum behind a particular disease that translates into the availability of funding. For instance, $R \& D$ on malaria vaccines has

69. There are, of course, many other forms of dealing with problems related to incentives. An emerging solution for incentives problems specific to the field of vaccines is the formation of public-private partnerships. See generally Margaret Chon et al., CAMBridge HANDBOOK ON Public-Private PARTNERShips, INTELlECTUAL PROPERTY GOVERNANCE, AND SUSTAINABLE DEVELOPMENT (July 25, 2018) https://papers.ssrn.com/sol3/papers.cfm?abstract_id=3219930 [https:// perma.cc/XP84-48D3].

70. See e.g. Gary Wong \& Xiangguo Qiu, Funding Vaccines for Emerging Infectious Diseases, HuMAN VACCINES \& IMMUNOTHERAPEUTICS (Jan. 16, 2018), https:/www.ncbi.nlm.nih.gov/pmc/articles/PMC6067896/

[https://perma.cc/8LWH-LGTQ].

71. See e.g. Nicole Wetsman, Health Secretary Alex Azar Won't Promise that a Coronavirus Vaccine Would Be Affordable, THE VERGE (Feb. 27, 2020), https:/www.theverge.com/2020/2/27/21155879/alex-azar-coronavirus-vaccineaffordable-insurance [https://perma.cc/H9VQ-U573]; Gerald Posner, Big Pharma May Pose an Obstacle to Vaccine Development, N.Y. TIMES (Mar. 2, 2020), https://www.nytimes.com/2020/03/02/opinion/contributors/pharma-vaccines.html [https://perma.cc/6X84-QY7R].

72. See e.g. Daniel Hemel \& Lisa Larrimore Ouellette, Want a Coronavirus Vaccine, Fast? Here's a Solution, TIME (Mar. 4, 2020), https://time.com/5795013/coronavirus-vaccine-prize-challenge/

[https://perma.cc/RX5Z-DLGC] (proposing the creation of an ad hoc prize for the development of coronavirus vaccines).

73. See supra notes $46-50$ and accompanying text. 
received financial support from sources such as the Bill \& Melinda Gates Foundation. ${ }^{74}$ This is also what happens when large infectious disease outbreaks drastically alter the incentives landscape-in an almost perverse way, as recently illustrated by the quick propagation of COVID-19, which cured the incentives problem almost overnight, resulting in an extraordinarily populated race to develop vaccines targeting the emerging pathogen. ${ }^{75}$

Curing the incentives problem - even if temporarily ${ }^{76}$ - does not necessarily guarantee that scientifically viable vaccines will come to market in a timely fashion or that they will be made available to indicated populations at affordable prices. While distinct, these two types of problems are rooted in the same (potential) malfunction of intellectual property regimes: it is possible for rightsholders to (mis)use their exclusionary power in ways that delay or curtail access to socially valuable goods because the incentives component of intellectual property, by design, rests on an exclusionary legal architecture. In this sense, the exclusionary tools used to promote innovation in the form of rights-as-incentives can be (mis) used at the transactional level, both when transfers of intellectual property are required for further development of biopharmaceutical products like vaccines and at the commercialization stage of fully developed and licensed products. This Essay now illustrates both problems in turn.

An example of the first scenario-transactional issues affecting transfers of vaccine-related intellectual property during R\&D stages-occurred during the 2014-16 Ebola outbreak. It involved the then-leading Ebola vaccine candidate in the wake of the 2014-15 outbreak for which a small American pharmaceutical company held a license issued by the Canadian government. ${ }^{77}$ The company, NewLink, failed to test the vaccine and seek regulatory

74. See, e.g., Leslie Wroughton, Gates Gives $\$ 168$ Mln for Malaria Vaccines Research, REUTERS (Sep. 25, 2018), https://www.reuters.com/article/us-unassembly-malariahealth/gates-gives-168-mln-for-malaria-vaccines-research-

idUSTRE48O9CD20080925; BILL \& MELINDA GATES FOUND., MALARIA STRATEGY OVERVIEW, https://www.gatesfoundation.org/what-we-do/globalhealth/malaria [https://perma.cc/Q7GL-4VLV] (last visited June 14, 2020).

75. See Thanh et al., supra note 9 and accompanying text.

76. Outbreak-spiked funding tends to thin out fairly quickly, a phenomenon that often begins even before the outbreak has ended. See Rutschman, IP Preparedness for Outbreak Diseases, supra note 57, at 1253 (addressing this problem with reference to Ebola R\&D in the later stages of the 2014-16 pandemic).

77. See generally Rutschman, supra note 57. 
approval in the years prior to the outbreak as required by the terms of the license. ${ }^{78}$ Moreover, as the outbreak unfolded, the company maintained the same course for a few months - neither developing the vaccine nor licensing to another company. ${ }^{79}$ NewLink initially paid the Canadian government $\$ 205,000$ for the license. ${ }^{80}$ When it finally agreed to transfer the rights over the vaccine candidate to another company, NewLink received $\$ 30$ million, with the possibility of an additional \$20 million payment should the vaccine candidate enter clinical trials. ${ }^{81}$

This example illustrates a problem stemming from the concentration of patent-protected technology in a single entity unwilling or incapable of developing it even when the incentives problem has been solved. Unlike COVID-19, most outbreaks so far have been more temporally and/or geographically limited; therefore, the failure to develop promising vaccine technology can come at a heightened cost in the context of infectious diseases. Patent hold-up ${ }^{82}$ during an outbreak, even if momentary, happens at a time of spiked funding, which is traditionally short-lived. Thus, rights-as-incentives that were granted for utilitarian purposes now stand in the way of maximization of funding and R\&D goodwill. ${ }^{83}$

The second type of problem that might occur at the transactional level concerns the pricing of, or access to, a vaccine that has overcome both the incentives problem and potential transactional problems during R\&D stages. Even if the development and licensure of a new vaccine constitutes a significant achievement from a

78. Denise Grady, Ebola Vaccine, Ready for Test, Sat on the Shelf, N.Y. TIMES (Oct. 23, 2014), https://www.nytimes.com/2014/10/24/health/without-lucrativemarket-potential-ebola-vaccine-was-shelved-for-years.html [https://perma.cc/EW 92-YV54].

79. Lisa Schnirring, NewLink, Merck Deal Boosts Prospects for Ebola Vaccine, CIDRAP (Nov. 24, 2014), http://www.cidrap.umn.edu/newsperspective/2014/11/newlink-merck-deal-boosts-prospects-ebola-vaccine [https://perma.cc/R7QQ-2G42].

80. Id.

81. Id.

82. For a general overview of the phenomenon of patent hold-up, see Thomas F. Cotter et al., Demystifying Patent Holdup, 76 WASH. \& LEE L. REV. 1501, 1501 (2019).

83. As well as possibly expedited regulatory review pathways available to products needed to target the pathogen causing an outbreak. See generally Stuart L. Nightingale et al., Emergency Use Authorization (EUA) to Enable Use of Needed Products in Civilian and Military Emergencies, United States, 13 EMERGING INFECTIOUS DISEASES 1046, 1046 (2007). 
scientific and technological perspective, that achievement will be significantly thwarted - at a minimum from a public health perspective - if that vaccine is not made available to those who need it. Yet, for the past several years, there have been recurrent concerns that emerging vaccines for infectious diseases might be priced in ways that effectively exclude segments of indicated populations from receiving it.

This was the case with Zika vaccine candidates in the wake of the $2015-16$ outbreak. ${ }^{84}$ During this time, scholars and policymakers alike worried that an exclusive license for the then-leading Zika vaccine candidate would grant a single company the de facto ability to price out poorer indicated populations. ${ }^{85}$ At this time, as dozens of vaccines targeting COVID-19 are under development, it is concerning that little has emerged to assure the public at large of the ultimate affordability of the vaccines. If anything, the opposite has happened. ${ }^{86}$

In late February 2020, when asked at a congressional hearing whether potential coronavirus vaccines would be "affordable for anyone who needs it," Secretary of Health and Human Services Alex Azar replied, "We would want to ensure that we work to make it affordable, but we can't control that price because we need the private sector to invest...Price controls won't get us there." 87

This statement pitches the incentives function of intellectual property against the exercise of exclusionary rights in the biopharmaceutical arena as if the two were not interdependent. Moreover, it implies that the rights-as-incentives do not have to be balanced first within the intellectual property universe and second

84. See generally Ana Santos Rutschman, Vaccine Licensure in the Public Interest: Lessons from the Development of the U.S. Army Zika Vaccine, 127 YALE L. J. F. 651, 651 (2018).

85. See e.g., Ed Silverman, The Battle Over a Fair Price for Zika Vaccines, STAT (May 18, 2017), https://www.scientificamerican.com/article/the-battle-overa-fair-price-for-zika-vaccines/. R\&D on this vaccine candidate has, in the meantime, stopped. See e.g., Helen Braswell, Sanofi Quietly Pulls the Plug on its Zika Vaccine Project, STAT (Sept. 2, 2017), https://www.statnews.com/2017/09/02/sanofi-zikavaccine/.

86. See Wetsman, supra note 71.

87. Isabel Togoh, Health Secretary Alex Azar Refuses to Guarantee Coronavirus Vaccine Would Be Affordable For All, FORBES (Feb. 27, 2020, 8:30 AM), https://www.forbes.com/sites/isabeltogoh/2020/02/27/health-secretary-alex-azarrefuses-to-guarantee-coronavirus-vaccine-would-be-affordable-forall/\#794efe16490c [https://perma.cc/KD3A-3B2E]. 
when measured against larger legal and policy goals and structures, including public health needs.

The recurrence of transactional malfunctions regarding vaccine technology in the field of infectious diseases is especially problematic as recent outbreaks remind us of the likely and imminent increase of our collective need for new vaccines as increased travel patterns, ${ }^{88}$ globalization, ${ }^{89}$ and climate change ${ }^{90}$ pose renewed challenges to public health. The following section considers how less property-centric treatments of intellectual property may help us work through some of the transactional problems we currently face in the field of vaccines.

This is not to say that there are not mechanisms embedded in intellectual property laws designed to curb the forms of intellectual property (mis)use surveyed above-from patent-specific provisions addressing the licensure of publicly funded goods ${ }^{91}$ or allowing government interventions ${ }^{92}$ to compulsory licensing mechanisms derived from international intellectual property laws. ${ }^{93}$ Rather, the point of this Essay is to suggest that we consider additional solutions, especially in light of the fact that many of these balancing mechanisms embedded into the legal architecture are seldom used (if used at all) ${ }^{94}$

\footnotetext{
88. See generally Mary E. Wilson, Travel and the Emergence of Infectious Diseases, 1 EMERGING INFECTIOUS DISEASES 39, 39 (1995), https://wwwnc.cdc.gov/eid/article/1/2/95-0201_article.

89. See generally Inst. MED., THE IMPACT OF GLOBALIZATION ON INFECTIOUS DiSEASE EMERGENCE AND CONTROL: WORKSHOP SUMMARY, STACEY KNOBLER ET AL., EDITORS, NAT'T ACADEMIES PRESS (2006), 1(Stacey Knobler et al. eds., 2006).

90. See generally U.S. Ctrs. Disease Control \& Prevention, , Climate EFFECTS ON HEALTH, https://www.cdc.gov/climateandhealth/effects/default.htm [https://perma.cc/55FM-MACT].

91. E.g., 35 U.S.C. § 209(a)(1) (2012); see also Rutschman, supra note 84.

92. E.g., 28 U.S.C. § 1498; see generally Hannah Brennan et al., A Prescription for Excessive Drug Pricing: Leveraging Government Patent Use for Health, 18 YALE J.L. \& TECH. 275, 308 (2016) (describing the applicability of 28 U.S.C. $§ 1498$ to pharmaceutical and biopharmaceutical products).

93. E.g., Agreement on Trade-Related Aspects of Intellectual Property Rights, 33 I.L.M. 319, 333-34 (1994) [hereinafter TRIPS Article 31]; see Frederick M. Abbott \& Rudolf Van Puymbroeck, Implementation of Paragraph 6 of the Doha Declaration on the TRIPS Agreement and Public Health, 61 WORLD BANK WORKING PAPER 51 (2005).

94. As is the case of compulsory licensing of pharmaceuticals. Other examples include government march-in rights associated with federally funded innovation. See generally Ryan Whalen, The Bayh-Dole Act \& Public Rights in Federally Funded Inventions: Will the Agencies Ever Go Marching In?, 109 Nw. U. L. REV. 1083, 1083 (2015).
} 
in the United States. The topic this Essay next turns to thus explores an alternative ${ }^{95}$ way of lessening the detrimental impact of overly exclusionary effects often associated with the transactional side of intellectual property rights in the field of vaccine R\&D. Specifically, one alternative is to adopt liability regimes that place less emphasis on the proprietary contours of patents by allowing the use of protected goods against the payment of just compensation to the patent holder. While exploring this topic entails some reference to the broader nature of intellectual property rights, and in particular a nod to the now storied yet unsettled debate surrounding the property question in patent law, this Essay addresses these questions narrowly with reference to the highly idiosyncratic field of vaccines.

\section{Property, Intellectual Property and Liability Rules}

In previous work, the Author has suggested that liability regimes constitute an overlooked solution to transactional problems affecting critical technology essential to the development of goods needed to address pressing public health needs. ${ }^{96}$ Here, the Author develops that theme by connecting it to the ongoing debate on the nature of intellectual property rights, as the adoption of liability regimes implies a departure from strong, proprietary conceptualizations of intellectual property rights. Part A will provide an overview of property-informed conceptions of patent rights in American caselaw. Part B will explain how liability regimes may coexist within proprietary frameworks and how sketches out how liability regimes can be implemented in the field of vaccines to help mitigate transactional problems during the later stages of vaccine R\&D.

\section{A. IP as Property}

The Patent Act establishes that "patents shall have the attributes of personal property. ${ }^{\prime 97}$ The extent to which patent rights should be regarded as a form of property proper-as opposed to a

95. And cumulative.

96. Rutschman, supra note 27, 765-69.

97. 35 U. S. C. $\$ 261$ (2013). 
distinguishable, more elusive legal form - has long prompted intense debate. ${ }^{98}$

The Supreme Court and the Federal Circuit have repeatedly emphasized the property dimensions of intellectual property rights and in particular of patents. In United States v. American Bell Telephone Co., Justice Miller framed patents as "private property of the patentee." 99

In Consolidated Fruit-Jar Co. v. Wright, a Supreme Court case involving a patent covering Mason jars, Justice Swayne stated that "[a] patent for an invention is as much property as a patent for land. The right rests on the same foundation, and is surrounded and protected by the same sanctions." 100 This property-coasting approach has persisted to this day. Just over a century after Consolidated Fruit Jar Co., writing for the majority in Florida Prepaid Postsecondary Education Expense Board v. College Savings Bank, Chief Justice Rehnquist characterized patents as a long-recognized "species of property." 101

Many of the analyses of the nature of patents as a form of property have arisen in the context of courts' discussions of the Takings Doctrine and its applicability to intellectual property. ${ }^{102}$ For instance, the Federal Circuit has applied the three-prong test that the Supreme Court developed in Penn Central to identify regulatory

98. For an overview of the scholarly debate see, e.g., Frank H. Easterbrook, Intellectual Property Is Still Property, 13 HARV. J.L. \& PUB. POL'Y 108, 108 (1990); Michael A. Carrier, Cabining Intellectual Property Through a Property Paradigm, 54 Duke L.J. 1 (2004); Stephen L. Carter, Does it Matter Whether Intellectual Property is Property?, 68 CHI.-KENT L. REV. 715 (1993).

99. U.S. v. Am. Bell Tel. Co., 128 U.S. 315, 370 (1888); see also Brown v. Duchesne, 60 U.S. 183, 197 (1856); McCormick Harvesting Mach. Co. v. Aultman, 169 U.S. 606, 609 (1898) (cited in Oil States, infra note 110).

100. Consol. Fruit-Jar Co. v. Wright, 94 U.S. 92, 96 (1876).

101. Fla. Prepaid Postsecondary Educ. Expense Bd. v. Coll. Sav. Bank, 527 U.S. 627, 642 (1999).

102. The articulation between intellectual property rights and the takings clause is often traced back to Madison's expansive framing of property: "Government is instituted to protect property of every sort" (emphasis added). James Madison, Property, PAPERS (Mar. 29, 1792), at 266. For a discussion of the evolution of the treatment of patents in connection with the Takings Clause, see generally Adam Mossoff, Patents as Constitutional Private Property: The Historical Protection of Patents Under the Takings Clause, 87 B.U. L. REV. 689 (2007); see also Thomas F. Cotter, Do Federal Uses of Intellectual Property Implicate the Fifth Amendment?, 50 FlA. L. REV. 529 (1998); Gregory Dolin \& Irena D. Manta, Taking Patents, 73 WASH. \& LEE L. REV. 719 (2016). 
takings of real property ${ }^{103}$ to cases involving patents. ${ }^{104}$ Citing Consolidated Fruit Jar Co., ${ }^{105}$ in Patlex Corp. v. Mossinghoff, Judge Newman wrote that "[i]t is beyond reasonable debate that patents are property." ${ }^{106}$ Grounded on this view of patent rights, the court went on to apply the Penn Central factors to analyze due process issues in the context of patent reexamination. ${ }^{107}$

In 2015, in Horne v. Department of Agriculture, the Supreme Court reiterated the idea that, for purposes of application of the Takings Clause, there is no differentiation between real and personal property. ${ }^{108}$ Gregory Dolin and Irina Manta have argued that this decision subjects patents to the Takings Clause. ${ }^{109}$

Most recently, while examining the constitutionality of inter partes review - an adversarial form of post-issuance administrative proceeding allowing the Patent and Trademark Office to reexamine patent grants - the Supreme Court in Oil States expressly declined to address the property question. ${ }^{110}$ In upholding the constitutionality of inter partes review, Justice Thomas, writing for the majority, emphasized the narrowness of the holding and stated that Oil States "should not be misconstrued as suggesting that patents are not property for purposes of the Due Process Clause or the Takings Clause." 111

103. Penn Cent. Transp. Co. v. N.Y.C., 438 U.S. 104, 124 (1978).

104. Patlex Corp. v. Mossinghoff, 758 F.2d 594, 602 (Fed. Cir. 1985).

105. And borrowing from Jeremy Bentham's utilitarian worldview of property and property rights. $I d$. at 599.

106. Id.

107. Id. at 603 (applying "the Penn Central standard to [the appellant's] property rights").

108. Horne v. Dep't of Agric., 135 S. Ct. 2419, 2426 (2015) ("Nothing in the text or history of the Takings Clause, or our precedents, suggests that the rule is any different when it comes to appropriation of personal property").

109. See Dolin \& Manta, supra note 102, at 771-72. Previously, in Zoltek, the Federal Circuit had concluded that the Takings Clause did not apply to patents. Zoltek Corp. v. United States, 442 F.3d 1345, 1353 (Fed. Cir. 2006). Camilla Hrdy and Ben Picozzi, however, have made the case that, while the Supreme Court has recognized that trade secrets have a "property-like nature," it has not definitively determined that patents should be regarded on equal footing with real property even for purposes of applying the Takings Clause. See Camilla A. Hrdy \& Ben Picozzi, The AIA is Not a Taking: A Response to Dolin \& Manta, 72 WASH. \& LEE L. REV. ONLINE 472, 475 (2016).

110. Oil States Energy Servs., LLC v. Greene's Energy Grp., LLC, 138 S. Ct. 1365,1370 (2018).

111. Id. at 1379. 
In reaching the conclusion that inter partes review does not violate "the Constitution by extinguishing private property rights through a non-Article III forum without a jury," 112 the Court examined the nature and characteristics of intellectual property rights from a different viewpoint. The Court distinguished between "public" and "private" rights and stated that "[p]atents convey only a specific form of property right - a public franchise," with inter partes review falling "squarely within the public-rights doctrine." 113

Thus, judicial forays into queries about the nature of intellectual property have tended to emphasize the property components of patent rights. While consistent with the statutory language and framework, this emphasis does not exclude the possibility of regarding patents as a differentiated form of propertyincluding viewing patents as grants or public franchises that are best described in non-property terms. By reserving the property question in Oil States, the Supreme Court left the door open to worldviews of intellectual property that are not centered on property features.

Moreover, even if patents were to be deemed a form of property proper - or essentially analogizable to property - the cases described above, as well as their progeny, have resorted to the property analogy predominantly in the context of applying the Takings Clause. This approach suggests that courts are primarily concerned with instances in which the economic dimensions traditionally associated with patent-attributable exclusivity are lessened. As seen in the following section, those concerns can be addressed even in instances in which liability regimes allow competitors to use patented technology — namely through principles of fair compensation.

112. Petition for a Writ of Certiorari at *i, Oil States Energy Servs. v. Greene's Energy Grp., 138 S.Ct. 1365 (2018) (No. 16-712).

113. Oil States Energy Servs., LLC, 138 S. Ct. at 1373, 1375. This distinction is not new in Supreme Court jurisprudence: the grant of a patent has long been regarded as the exercise of a public right; in United States v. American Bell Telephone Co., for instance, the Court characterized this grant as the act of an administrative agency which takes "public rights of immense value" and "bestow[s] them upon the patentee." United States v. Am. Bell Tel. Co., 128 U.S. 315, 370 (1888). 


\section{B. Liability Regimes in IP: A Solution for Vaccine R\&D During Public Health Crises?}

Liability rules, ${ }^{114}$ also known as "take-and-pay" regimes, allow follow-on innovators to pay an "objectively determined value" for someone else's entitlement. As Jack Balkin and Ian Ayres have put it, liability rules give "at least one party an option to take an entitlement non-consensually and pay the entitlement owner some exercise price." ${ }^{115}$ Consider the case of the Ebola vaccine candidate described in Part II. ${ }^{116}$ Under property rules, a follow-on innovator wishing to quickly develop and test a vaccine candidate as early as possible during an outbreak would need to not only obtain NewLink's permission but also to support the transaction costs associated with the bargaining and licensure processes, which are likely to spread over a significant period of time. Under a system of liability rules, however, the same follow-on innovator would be able to "non-consensually" take the technology needed to make this vaccine candidate upon payment of an "objectively determined value."

Liability regimes thus accomplish two things. They eliminate the threshold question of whether a patentee will even negotiate a license in the first place. And they lower transaction costs by reducing the bargaining process to a determination of the value of the entitlement.

These features of liability regimes render them especially apt to facilitate certain transfers of technology during situations of public health crisis - particularly in the case of severe or pandemic outbreaks of infectious diseases. From a legal perspective, because the Supreme Court has reserved the property question, there is no doctrinal or precedential impediment to recognizing that patent regimes, or at least certain aspects thereof, are not completely analogizable to property regimes. From a policy perspective, infusing some pockets of patent law and practice with liability features - or micro-liability regimeswould result in a nimbler legal architecture for innovators during periods of public health crisis. And from a political economy

114. As opposed to property rules, in the Calabresi-Melamed formulation. See Guido Calabresi \& A. Douglas Melamed, Property Rules, Liability Rules, and Inalienability: One View of the Cathedral, 85 HARV. L. REV. 1089, 1092 (1972).

115. Jack M. Balkin \& Ian Ayres, Legal Entitlements as Auctions: Property Rules, Liability Rules, and Beyond, 106 YALE L. J. 703,704 (1996).

116. See generally supra notes 77-81 and accompanying text. 
perspective, because the approach proposed in this Essay is limited to very specific sets of technology needed for expedited vaccine R\&D during abnormal public health circumstances, the disruption to established interests would be relatively moderate and limited in both scope and time.

This Essay does not support the view that a liability regime is desirable for all features of vaccine innovation. As a form of technology based on the weakening or killing of a pathogen, vaccines constitute a fairly old form of technology. ${ }^{117}$ Within the field of vaccines, however, many components of contemporary vaccine technology (such as certain adjuvants), as well as emerging vaccine platform technology ${ }^{118}$ (such as mRNA-based vaccines), ${ }^{119}$ are the product of much more complex $R \& D$ processes than the ones associated with vaccine innovation through most of the twentieth century. The Author has contended elsewhere that liability regimes, even in situations of pronounced health care need, should be restricted to "low hanging fruit:" simpler forms of vaccine technology not the latest advancements in the field of vaccinology, immunology, and related fields. ${ }^{120}$ The reason behind this distinction is twofold. First, it acknowledges the political economy of contemporary innovation in biotech, which depends in significant part on the engagement of the private sector. ${ }^{121}$ And second, it is mindful of the fact that the adoption of an explicit liability regime in patent law_-even if restricted to a subsector of R\&D occurring during formally declared public health

117. See Rutschman, The Vaccine Race, at 738. See also generally Alexandra Minna Stern \& Howard Markel, The History of Vaccines and Immunization: Familiar Patterns, New Challenges, 24 HeALTH AFF. 611 (2005).

118. See Vaccine Platforms: State of the Field and Looming Challenges, JoHns HOPKINS CTR. FOR HEALTH SECURITY (2019), https://www.centerforhealthsecurity .org/our-work/pubs_archive/pubs-pdfs/2019/190423-OPP-platform-report.pdf [https://perma.cc/VZZ2F-QJ8J] (adopting the Webster Dictionary definition of platform as "a vehicle used for a particular purpose or to carry a usually specified type of equipment."); see also WHO EXPERT COMMITTEE ON BIOLOGICAL STANDARDIZATION: SIXTY-EIGHT REPORT 95 (WHO Technology Report Series, No. 1011 2018) (defining the concept as "a production technology with which different viral vectored vaccines are produced by incorporating heterologous genes for different proteins into an identical viral vector backbone").

119. See Norberto Pardi et al., mRNA Vaccines - A New Era in Vaccinology, 17 NATURE REVS. DRUG DisCOVERY 261, 261 (2018).

120. See Rutschman, Vaccine Race, 760-762.

121. See Liza Vertinsky et al., The Problem with Relying on Profits to Produce Pandemic Drugs, (forthcoming, 2020) (manuscript on file with author). 
crises - would constitute an exceptional legal regime and as such should be designed as narrowly as possible.

The ongoing COVID-19 vaccine race illustrates the need for this distinction. As of mid-April 2020, over 100 R\&D projects existed. ${ }^{122}$ Some of these projects relied on older forms of vaccine development such as inactivation or attenuation of the virus. ${ }^{123}$ Yet others relied on DNA and RNA vaccine technology, ${ }^{124}$ which constitute a recent development in vaccine $\mathrm{R} \& \mathrm{D}$ and are still in the early stages of development. ${ }^{125}$ For further context, consider how the World Health Organization has described the emergence of DNA vaccine technology as opposed to pre-existing types of vaccine R\&D:

For over a hundred years vaccination has been [a]ffected by one of two approaches: either introducing specific antigens against which the immune system reacts directly; or introducing live attenuated infectious agents that replicate within the host without causing disease synthesize the antigens that subsequently prime the immune system. Recently, a radically new approach to vaccination has been developed. It involves the direct introduction into appropriate tissues of a plasmid containing the DNA sequence encoding the antigen(s) against which an immune response is sought, and relies on the in situ production of the target antigen. This approach offers a number of potential advantages over traditional approaches... ${ }^{126}$

A liability regime would be appropriate for less recent forms of vaccine technology or components thereof, not for emerging ones.

122. See Tung et al., supra note 9 , at 305.

123. Id.

124. Id. See also DNA Vaccines, World HeAlth OrG., https://www.who.int/biologicals/areas/vaccines/dna/en/ [https://perma.cc/8SYG22BU] (last visited Jul. 10, 2020); Laura Blackburn, RNA Vaccines: An Introduction, PHG FOUND. (Oct. 2018), https://www.phgfoundation.org/documents/rna-vaccinesan-introduction-briefing-note.pdf [https://perma.cc/SWJ7-GPP8].

125. See Tung et al., supra note 9, at 305; see also DNA Vaccines, WorLD HEALTH ORG., https://www.who.int/biologicals/areas/vaccines/dna/en/ [https:// perma.cc/8SYG-22BU] (last visited Jul. 10, 2020); Laura Blackburn, $R N A$ Vaccines: An Introduction, PHG Found. (Oct. 2018), https:/www.phgfoundation .org/documents/rna-vaccines-an-introduction-briefing-note.pdf [https://perma. cc/SWJ7-GPP8].

126. DNA Vaccines, WORLD HEALTH ORG., https://www.who.int/biologicals /areas/vaccines/dna/en/ [https://perma.cc/8SYG-22BU] (last visited Jul. 10, 2020). 
For instance, the vaccine candidate that the U.S. Army developed in a matter of months during the 2015-16 Zika outbreak, ZPIV (Zika purified inactivated virus), ${ }^{127}$ was based on pre-existing vaccine technology that the Army developed in connection with a different virus in the Zika family. ${ }^{128}$ Thus, long-established forms of vaccine technology can be quickly used to target emerging pathogens, and limiting a liability regime to some forms of vaccine technology - and even a limited number of components - is not incompatible with covering a significant amount of technology, while preserving the status quo of the vaccine innovation ecosystem for players involved in evolving forms of vaccine R\&D.

Having considered the scope of the proposed liability regime approach, this Essay concludes by outlining possibilities for the establishment of such a regime. First, in line with the restrictive nature of the proposal, the liability regime would only apply to a limited set of technologies needed in vaccine R\&D for infectious diseases in the event of a public health crisis. An entity (or a combination of entities) in the public heath space would make both the determination of the components integrated in this regime and the qualification of "public health crisis." Examples of these entities include the U.S. National Institutes of Health, the Centers for Disease Control and Prevention, or the World Health Organization. The formal event that would trigger the activation of the liability could be a declaration of a public health crisis - for instance, a declaration of public health emergency by the Department of Health and Human Services ${ }^{129}$ or a declaration of a public health emergency of international concern by the World Health Organization. ${ }^{130}$

127. See, e.g., Trials Show Inactivated Zika Virus Vaccines is Safe and Immunogenic, NAT'L INST. OF ALLERGY AND INFECTIOUS DISEASES (Dec. 4, 2017), https://www.niaid.nih.gov/news-events/trials-show-inactivated-zika-virus-vaccinesafe-and-immunogenic [https://perma.cc/6HPK-LEBL].

128. See id; see also Rutschman, supra note 84 , at 654 . For a timeline of this particular R\&D project see Rutschman, supra note 84.

129. Public Health Emergency Declaration, U.S. DEP'T. OF HEALTH \& HuM. SERVS., https://www.phe.gov/Preparedness/legal/Pages/phedeclaration.aspx [https ://perma.cc/JBL4-TDYH] (last updated Nov. 26, 2019).

130. IHR Procedures Concerning Public Health Emergencies of International Concern (PHEIC), WORLD HEALTH ORG., https://www.who.int/ihr/procedures/pheic/en/ [https://perma.cc/X4AH-A3TN] (last visited Jul. 10, 2020). 
Second, a "taking" of vaccine technology under the liability regime - a duration that could be established to match the duration of the formally declared public health emergency — would be subject to the payment of just compensation. ${ }^{131}$ In an ideal formulation, the "objectively determined value" of the liability entitlement would be established ex ante to reduce uncertainty, friction between original and follow-on innovators, and the likelihood necessary court intervention. This ex ante determination could be set in the form of a "price menu." Instead of a fixed price, the "menu" could also be implemented through the adoption of a formula, which could be used ex post by the parties. ${ }^{132}$

And third, the most straightforward way to implement such a regime would be through legislative intervention. This could be accomplished by enacting a law that either defines which vaccinerelated technology components are subject to a liability regime or grants a particular institutional actor this definitional power. ${ }^{133}$ This suggestion mirrors what happened in the case of the priority review vouchers currently administered by the U.S. Food and Drug Administration, which apply to selected diseases-primarily neglected tropical diseases - and were originally defined by Congress but later expanded on as public health emergencies arose. ${ }^{134}$

As noted above, applying liability rules furthers economic efficiency by reducing bargaining uncertainty and transaction costs. Furthermore, a regime like the one sketched in this Essay would be beneficial from a distributive justice perspective because it would facilitate the development of, and access to, critical health technologies that are sorely needed to improve preparedness in an era of increasing globalized outbreaks of infectious diseases.

131. See generally Balkin \& Ayres, supra note 115 and accompanying text.

132. The exact formulation of the "price menu" would be best developed by experts in economics and other relevant fields.

133. Such as the case of the agencies and international organization alluded to above. Supra notes 129-130 and accompanying text.

134. See Ana Santos Rutschman, The Priority Review Voucher Program at the FDA: From Neglected Tropical Diseases to the 21st Century Cures Act, 26 ANNALS HEALTH L. 71, 71 (2017). 